\title{
Developing a Distance Education Self-Efficacy Belief Scale: A Validity and Reliability Study
}

\author{
Alper Altunçekiç* \\ Computer Technologies, Gazi University, Ankara, Turkey
}

ORCID: 0000-0002-3649-0991

Article history

Received:

01.04.2021

Received in revised form:

01.07.2021

Accepted:

07.07.2021

Key words:

Distance education;

Self-efficacy,

Scale,

Belief
In this research, a measurement tool was developed to determine the selfefficacy belief levels of university students towards distance education. The study group consists of 438 university students (297 women, 141 men) who continue their education activities with distance education in the 2021-2022 academic year. The scale development process has progressed according to the steps in the scale development stages. Various statistical analyses were conducted to provide evidence for the reliability and validity of the Distance Education Self-Efficacy Belief Scale. It was aimed to create evidence for the construct validity of the scale by making Exploratory Factor Analysis. Since there was no repetition of the developed scale, only Exploratory Factor Analysis was performed. As a result of factor analysis, the Cronbach Alpha coefficient of the scale was calculated as .92 . This coefficient is the proof that the developed scale can measure the measurement process consistently. In addition, the fact that the scale items regarding the item-total correlation values have values between .45 and .71 is an indication that the scale has the ability to measure the features desired to be measured, in short, it serves the purpose of its development. Findings from the scale show that the scale can be used to determine distance education self-efficacy belief levels.

\section{INTRODUCTION}

Distance education is a type of education in which individuals can carry out their learning activities regardless of the time and location in line with their current technological opportunities. Aydemir (2018) defined distance education as an education-teaching system regardless of time and space in which individuals share information with technological tools and applications and establish communication and interaction. Schlosser \& Simonson (2009) stated that distance education can be used together with face-to-face models and other education-teaching methods and techniques. However, distance education appears as the only alternative in the situations that will prevent students from continuing their education institutions. Because, during the global epidemic that affects the whole world today, distance education has been the most important option for the continuation of education. This situation has attracted the attention of many researchers and studies on distance education have

\footnotetext{
*Correspondency: altuncekic@gmail.com
} 
increased rapidly since 2019. The results obtained from the studies show that the knowledge, skills and experiences of teachers and students about distance education are important in the effectiveness of distance education. In their research, Tarlakazan \& Tarlakazan (2020) stated that teachers and students need more support and experience in distance education. As a result of another study conducted by Akıncı \& Pişkin Tunç (2021), it was emphasized that support for the teaching process, evaluation process, material and technical infrastructure is important for the distance education process to be more efficient. The problems experienced by individuals in distance education processes can cause perceptions of distance education to be negatively affected. This may adversely affect the learning performance of individuals.

It is known that many factors such as interest, motivation, attitude, problem solving, selfefficacy are effective in the realization of learning (Randel, Stevenson, \& Witruk, 2000). Arguably the relationship between success, self-confidence and motivation is positive (Jacobsen, Eggen, \& Kauchak, 2002). For this reason, there is a need for regulations that enable to increase these skills of students together. With the development of these skills, the purpose of education is realized. Because when individuals feel confident in themselves, they feel better in the learning process and thus high-level learning occurs (Ornstein \& Lasley, 2000). Bloom (1979) in his research conducted in seventeen different countries, stated that there is a relationship between affective characteristics towards the course and success. Therefore, in order for students to develop positive attitudes towards learning, education should be organized according to students' interests and needs. One of the factors that motivate students in learning is self-efficacy.

Competence, which Bandura defines as "the ability to successfully use the ability to take action to achieve a specific goal," is explained in two components: self-efficacy and outcome expectation (Anderson, Dragsted, Evans, \& Sorenson, 2004). Self-efficacy is defined as being aware of and believing in one's abilities to do a job (Chaplin, 2000; Zusho \& Pintrich, 2003). Downey (2006) defined the concept of self-efficacy as the belief that an individual can successfully perform a given task or behavior. (Santiago \& Einerson, 1998; Schriver \& Czerniak, 1999). Bandura stated that self-efficacy belief plays a vital role in an individual's success in different conditions (Freidmen, 2003). Individuals with low self-efficacy levels act timidly when faced with difficult tasks and perceive these tasks as a personal threat. This situation causes them to have a low level of responsibility in reaching their goals and to give up quickly (Yaman, Cansüngü Koray \& Altunçekiç, 2004). Individuals with a high perception of self-efficacy in any subject show the ability to reach the result in a shorter time. Because individuals with high self-efficacy perception are more successful in solving the problems they encounter. Aşkar \& Umay (2001) stated that individuals with high self-efficacy perceptions try harder to achieve success in a job, and are persistent and patient without giving up when faced with negativities. It is obvious that individuals with high self-efficacy beliefs will strive to overcome the problem without giving up on the obstacles they may encounter in technology use.

The results of the study by Ertmer et al. (2012) show that attitudes and beliefs are one of the strongest barriers to technology use. Naylor \& Nyanjom (2020) stated that technical problems in distance education environments cause negative feelings such as stress and anxiety on teachers. Can (2020), on the other hand, emphasized that perceptions and expectations towards distance education are one of the determining factors in the use of distance education environments by instructors. In another study conducted by Woodcock, Sisco, \& Eady (2015), it was concluded that students' self-efficacy perceptions towards online learning environments are one of the important factors affecting the education-teaching process. For this reason, it is 
accepted that measuring these skills of students is an important factor for increasing the quality of the education process.

Although there are scales in the literature that allow the determination of many different features in the field of distance education, it is seen that the number of scales developed to determine the level of self-efficacy for distance education is limited. In this study, it was aimed to develop a measurement tool with a high level of validity and reliability in order to shed light to evaluating distance education processes effectively and efficiently by determining the self-efficacy levels of individuals for distance education processes. Thus, it will be possible to determine students' self-efficacy belief levels and to better direct their education processes in online learning environments that are rapidly increasing with the pandemic in Turkey and in the world.

\section{METHOD}

This study focuses on the development of a scale. The processes related to the development of the scale are given below.

\section{Sample}

The sample of the research consists of 438 university students studying distance education in different state universities in the 2021-2022 academic year. Child (2006) stated that the sample size of five times the number of items is sufficient in scale development studies. According to this information, it can be said that the number of students participating in the research is sufficient for the scale development study. In Table 1, the descriptive statistics results of the study group are given.

Table 1. Descriptive statistics for the sample

\begin{tabular}{llll}
\hline & Variable & N & $\%$ \\
\hline \multirow{2}{*}{ Gender } & Female & 297 & 67.8 \\
& Male & 141 & 32.2 \\
\hline \multirow{4}{*}{ Class } & Class 1 & 71 & 16.2 \\
& Class 2 & 147 & 33.6 \\
& Class 3 & 110 & 25.1 \\
& Class 4 & 110 & 25.1 \\
\hline \multirow{3}{*}{ Device } & Desktop Computer & 46 & 10.5 \\
& Laptop & 277 & 63.2 \\
& Tablet PC & 14 & 3.2 \\
\hline Total & Mobile Phone & 101 & 23.1 \\
\hline
\end{tabular}

\section{Stages of Scale Development Study}

Studies in the literature on self-efficacy towards distance education were examined and it was seen that there were a limited number of self-efficacy belief scales (Horzum \& Çakır, 2009; Yıldız, 2015; Öztürk \& Kert, 2017). In these studies, the self-efficacy belief dimension was generally included in different scales such as attitude or adapted from a different language to Turkish. To that end, the distance education self-efficacy belief scale development process was carried out by the researcher following the steps seen in Figure 1. 


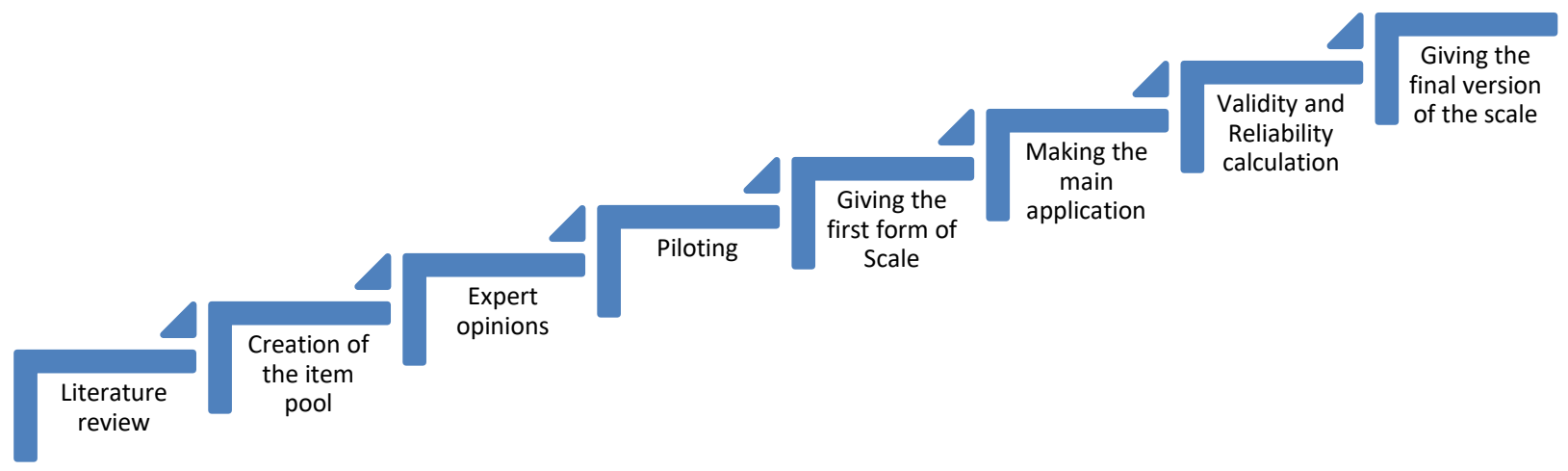

Figure 1. Scale development stages

\section{Data Collection}

A pool of 26 items was created for the scale by reviewing the literature and considering the basic dimensions in the relevant field. After the items in the pool were examined by field experts and language experts, it was decided to remove 5 items from the scale and a final scale form consisting of 21 items was created. The main reasons for the removal of the items are that the statements of the two items are also included in the other items and three items are not related to the scope of self-efficacy.

After this stage, 20 volunteer undergraduate students were asked to read the 21-item form and were asked if there were any items they did not understand, wanted clarification, or contradicted. Arrangements were made regarding the items that some of the participant students required an explanation, and those items were finalized by taking the opinions of these participants again.

In order to determine the participants' level of agreement with the items in the scale, a Likerttype 5-point rating scale was created as "I never agree", "I rarely agree", "I agree moderately", "I usually agree" and "I always agree". While negative expressions were not included in the creation of the items, 5 points reflected the most positive opinion and 1 point reflected the most negative opinion for all items. The prepared scale was sent to the participants in the digital environment and they were asked to respond on a voluntary basis.

\section{Data Analysis}

In this study, studies were conducted to determine the level of validity and reliability in order to measure the self-efficacy belief levels towards distance education. For this purpose, factor analysis was used for the construct validity of the measurement tool. Factor analysis is one of the most preferred methods in determining the construct validity of a scale. The main purpose of the factor analysis is dimension reduction (Yaşlıoğlu, 2017). Although there are different analyzes regarding the construct validity of the scale, exploratory factor analysis (EFA) was preferred in this study. Based on the relationships between the variables, the process to find new factors by grouping the variables is called exploratory factor analysis (EFA) (Büyüköztürk, Factor Analysis: Basic Concepts and Using to Development Scale, 2002). Since the research is a new scale development study, there is no repetition in a similar sample. Therefore, confirmatory factor analysis was not performed. Because confirmatory factor analysis is performed to check whether a previously used scale is suitable for the original factor structure if it is used in current research (as cited in Yaşlioğlu, 2017). 
Explanatory factor analysis (EFA) is used in the development of measurement tools (questionnaire, test, etc.), and confirmatory factor analysis (CFA) is used in testing whether the model that emerges with the developed scale is confirmed on the sample (Akyüz, 2018).

In order to determine the reliability level of the measurement tool, Cronbach Alpha method was used which is the most preferred for graded scales. Cronbach Alpha is widely used to determine the reliability of the scales used in the measurements of psychological characteristics (Kula Kartal \& Mor Dirlik, 2016). Cronbach's Alpha coefficient is a consistency estimation method where scale items are not scored as true or false, and is appropriate to be used in scales for sequential scoring such as 1-3, 1-5, 1-7 (Cronbach, 1951). Since reliability is a prerequisite for the validity of the measurement tool, firstly, the 21-item form was analyzed. With this process, the contribution of each item to the total reliability level as well as the corrected item-total score correlation values were examined. When all the items were examined, it was determined that the lowest corrected item-total score correlation range value was .25 (the highest value was .70, the lowest value was .45). Considering these values, it was accepted that this 21 -item form was sufficient.

As a result of the factor analysis performed after this process, it was decided to exclude the two items from the test due to the overlapping of the load values. In the reliability determination process after these two items were removed, the corrected item-total score correlation range of the remaining 19 items was determined to be .26 (highest .71, lowest .45).

\section{RESULTS}

In this part of the research, the results of the statistical analysis conducted to determine the validity and reliability levels of the Self-Efficacy Belief Scale for Distance Education are included.

\section{Recent Findings on Reliability}

Total test correlations were calculated in order to determine whether the items in the Self-Efficacy Belief Scale for Distance Education measure the desired feature. In order to determine the reliability of the scale, the Cronbach Alpha coefficients of the sub-factors were calculated. As a result of the internal consistency coefficients obtained from the sub-factors, the general Cronbach Alpha coefficient of the distance education self-efficacy belief scale was revealed. In Table 2, the general Cronbach Alpha coefficient regarding the items of the scale and the scale is given.

Table 2. Distance Education Self-efficacy belief scale reliability analysis results

\begin{tabular}{|c|c|c|c|c|c|c|}
\hline Items & \multicolumn{4}{|c|}{ Item Total Test Correlation } & & \multirow{11}{*}{ 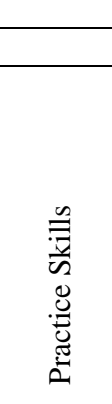 } \\
\hline & Factor 1 & Factor 2 & Factor 3 & Cr $\alpha$ & & \\
\hline I11 & .631 & & & .918 & \multirow{9}{*}{$\begin{array}{l}\text { Cr } \alpha: \\
.920\end{array}$} & \\
\hline I 7 & .602 & & & .919 & & \\
\hline I 5 & .533 & & & .920 & & \\
\hline I 6 & .519 & & & .920 & & \\
\hline I 10 & .603 & & & .919 & & \\
\hline I 8 & .599 & & & .919 & & \\
\hline I 2 & .563 & & & .920 & & \\
\hline I 9 & .567 & & & .920 & & \\
\hline I 3 & .452 & & & .922 & & \\
\hline I 16 & & .628 & & .918 & & \\
\hline I 17 & & .578 & & .919 & Cra: & -0 \\
\hline I 20 & & .594 & & .919 & .919 & 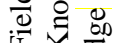 \\
\hline I 18 & & .710 & & .916 & & Ið \\
\hline
\end{tabular}


I 15

I 21

I 13

I 12

I 19

I 14
.615

.513

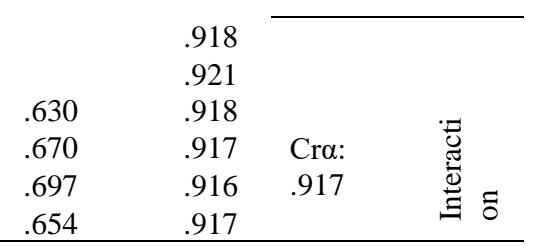

Table 2 includes the item total test correlation values for the items in the distance education self-efficacy belief scale, the Cronbach Alpha coefficients of the items, and the Cronbach Alpha coefficients of the factors. Item-total test correlations were found to be between .452 and .631 for the first factor, between .513 and .710 for the second factor, and between .630 and 697 for the third factor. An item total correlation value of .30 and above can be considered sufficient for item validity. The item-total correlation values of the scale being .30 and above indicates that the scale items have the ability to measure a feature, that is, they serve the purpose of measuring the features (Aslan \& Kan, 2021).

The Cronbach Alpha coefficient calculated for all the items in the Self-Efficacy Belief Scale for Distance Education was found to be .923 . In order to say that the reliability of a scale is high, the internal consistency coefficient should be .70 and above (Büyüköztürk, 2011; Tavşanc1l, 2014). The fact that the Cronbach Alpha coefficient (.923) of the developed scale was greater than this critical value was accepted as proof that the scale gave reliable results.

\section{Findings Regarding Validity}

In the study, firstly, procedures were carried out to determine whether the collected data were suitable for factor analysis. It was checked whether the correlation coefficients obtained by examining the relations of each item with other items were in the range of 0.10 to 0.90 , and it was determined that the correlation coefficients for the other items were in this range, except for 2 items. Then, the results of Kaiser-Meyer-Olkin (KMO) and Bartlett's Test of Sphericity (BTS) were examined. It was determined that the KMO value was 0.92 . The fact that this value is greater than 0.50 means that factor analysis can be done for the collected data. Field (2005) stated that the KMO value should be greater than 0.60 in order to perform factor analysis. BTS results (Aslan \& Kan, 2021) performed to check whether the data have a multivariate normal distribution feature were also found to be significant. $\left(\chi^{2}=4269.77\right.$; $p$ $=0.00$ ). As a result of the factor analysis performed by removing 2 items with a low correlation coefficient from the scale, it was determined that a structure with 3 sub-factors emerged. The slope graph was examined for the eigenvalues of each emerged factor. 


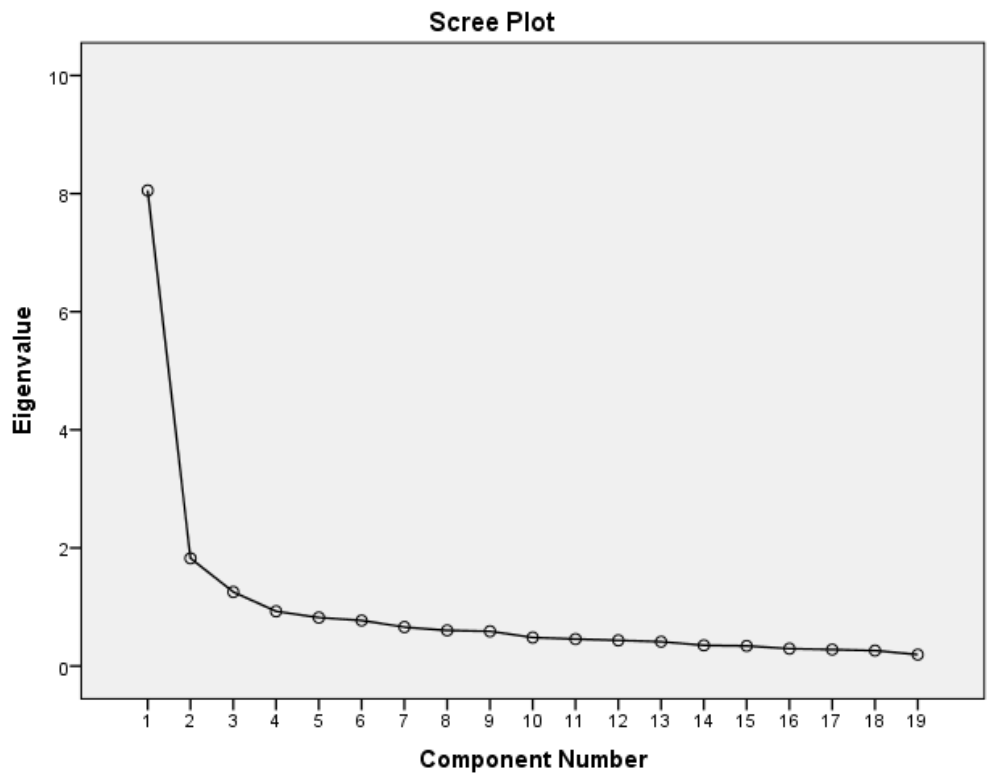

Figure 2. Scree Plot

The eigenvalue graph provides information that can be evidence about the structure of the developed scale besides the eigenvalue itself (Yaman, 2016). According to the eigenvalue graph, the eigenvalue of the first factor was found to be 8.05 and this factor consists of 9 items. This factor explains $39.96 \%$ of the self-efficacy belief scale. The eigenvalue coefficient of the second factor was found to be 1.82, and the number of items it contains is 6 . This explains $7.22 \%$ of the scale. The eigenvalue coefficient of the third and last sub-dimension is found as 1.25 . This sub-factor consisting of 4 items explains $4.45 \%$ of the scale.

Table 3. Factor load values and descriptive statistical results for the items of the self-efficacy belief scale

\begin{tabular}{|c|c|c|c|c|c|c|}
\hline Items & Factor 1 & Factor 2 & Factor 3 & $\overline{\mathrm{X}}$ & $S$ & \\
\hline M11 & .73 & & & 3.35 & .91 & \\
\hline M7 & .70 & & & 3.39 & .77 & \\
\hline M5 & .66 & & & 3.61 & .70 & \\
\hline M6 & .64 & & & 2.93 & .89 & \\
\hline M10 & .61 & & & 3.26 & 1.03 & $\triangleq$ \\
\hline M8 & .55 & & & 2.77 & 1.09 & $\frac{\pi}{5}$ \\
\hline M2 & .54 & & & 3.54 & .73 & 8 \\
\hline M9 & .49 & & & 2.60 & 1.07 & $\overline{0}$ \\
\hline M3 & .42 & & & 3.41 & .88 & $\Xi$ \\
\hline M16 & & .69 & & 3.29 & .99 & \\
\hline M17 & & .68 & & 3.49 & .88 & \\
\hline M20 & & .63 & & 3.18 & 1.00 & 8 \\
\hline M18 & & .60 & & 3.34 & .87 & $\frac{\sigma}{2}$ \\
\hline M15 & & .56 & & 3.34 & .87 & $\frac{\pi}{0}$ \\
\hline M21 & & .55 & & 3.22 & .96 & 玒 \\
\hline M13 & & & .78 & 2.25 & 1.05 & \\
\hline M12 & & & .78 & 2.75 & 1.09 & ב्ב \\
\hline M19 & & & .71 & 2.51 & 1.06 & $\pi$ \\
\hline M14 & & & .62 & 2.51 & 1.08 & $\stackrel{\Xi}{\Xi}=$ \\
\hline
\end{tabular}

When Table 3 is examined, it is seen that there are 9 items in the first factor, 6 items in the second factor, and 4 items in the third factor. According to (MacCallum, Widaman, Zhang, \& 
Hong (1999), it is recommended to have at least 3 items in a factor in measurement tools. The fact that the minimum number of items in a factor is 4 in the factorization of this scale shows that this condition is met. Factor load values explain the relationship of the items with the factors. Büyüköztürk, (2011) stated that values of 0.60 and above of factor loads can be defined as high, and values between $0.30-0.59$ can be defined as moderate magnitudes. Accordingly, it can be said that 16 of the items in the self-efficacy belief scale have a high factor load and 3 items have a moderate factor load.

The factors that emerged as a result of the factor analysis in the measurement tool can be named as follows:

(1) First factor: distance education application skills,

(2) Second factor: field knowledge in distance education trainings,

(3) Third factor: interaction in distance education

\section{Discussion, Conclusion and Recommendations}

In the research, a scale was developed in order to reveal the self-efficacy belief levels of individuals towards distance education. The scale consists of 19 items and 3 sub-factors. 9 items in the scale aim to reveal individuals' distance education application skills, 6 items their field knowledge in distance education, and 4 items their self-efficacy belief levels for interaction in distance education. The validity and reliability analyses revealed that the scale items can make adequate measurements in terms of validity and reliability.

It is important to maintain the process effectively in order for individuals to benefit from distance education. The problems experienced by individuals during the process may increase anxiety towards distance education. This increase in the level of anxiety may negatively affect the self-efficacy belief level of individuals (Ghaith \& Shaaban, 1999). Low self-efficacy belief levels may cause various risks in individuals' achievement or performance (Akkoyunlu, Orhan, \& Umay, 2005; Yıldız, 2015; Yıldız \& Seferoğlu, 2020).

On the other hand, it has been proven by different studies that the academic success of individuals with high self-efficacy belief levels is also high. Öztürk \& Kert (2017) concluded in their study on effects of online learning environment on adults' self-efficacy and academic achievement that the online learning environment has a positive effect on the academic achievement of adults. This result coincides with Yıldız \& Seferoğlu's (2020) view that students' self-efficacy perceptions can contribute to the process in instructional activities. In another study conducted by Çavuş \& Gökdaş (2006), it was concluded that the training received by teachers and prospective teachers on using internet for educational purposes, positively affects their professional success and self-efficacy beliefs. Patricia (2020), on the other hand, stated that features such as motivation, self-efficacy and technology use play an important role in the academic performance of individuals.

Another finding obtained as a result of the study conducted by Ateş \& Altun (2008) is that the level of self-efficacy perception is also effective on individuals' preference for online distance education. In the study conducted by Tarlakazan \& Tarlakazan (2020), they stated that individuals need more support and experience regarding distance education. This result indicates that if individuals are provided with adequate training and support, their selfefficacy belief levels towards distance education can increase and the distance education process can yield more successful results.

The fact that 438 undergraduate university students were reached is among the limitations of 
the study. Because the error will be less in larger samples. In addition, another limitation is that the developed scale could not be applied to different sample groups, and therefore, confirmatory factor analysis (CFA) was not performed. It is recommended that this scale developed by the authors in this study, be applied in different sample groups to create repeated measurements and apply confirmatory factor analyzes on the obtained data. In addition, it would be useful to use this measurement tool together with scales in which different variables are measured. It is accepted that studies to be carried out in the form of multiple matrices will provide important evidence in testing the level of validity of the data obtained from the measurement tool.

Since the scale was developed in Turkish, additional processes and analyses are needed to use it in different languages. Therefore, the Turkish form of the scale is also provided. It is suggested to researchers that the scale should be adapted to different languages and used, including different cultural characteristics. 


\section{REFERENCES}

Akıncı, M., \& Pişkin Tunç, M. (2021). The Problems Encountered by Pre-Service Mathematics Teachers in Distance Education Practices and Solution Suggestions. Ekev Journal of Academi, 25(85), 359-376.

Akkoyunlu, B., Orhan, F., \& Umay, A. (2005). A Study On Developing Teacher Self Efficacy Scale For Computer Teachers. Hacettepe University Journal of Education, 29, 1-8.

Akyüz, H. (2018). Confirmatory Factor Analysis for Construct Validity: An Applied Study. Bitlis Eren University Journal of Science, 7(2), 186-198.

Anderson, M. A., Dragsted, S., Evans, R., \& Sorenson, H. (2004). The Relationship Between Changes in Teachers' Selfefficacy Beliefs and the Science Teaching Environment of Danish First-Year Elementary Teachers. Journal of Science TEacher Education, 15(1), 25-38.

Aslan, S., \& Kan, A. (2021). A Validity And Reliability Study On The Scale For The Attitude Toward Syrian Students. The Journal of Turkish Social Research, 25(1), 193-206.

Aşkar, P., \& Umay, A. (2001). Perceived Computer Self-Efficacy Of The Students In The Elementary Mathematics Teaching Programme. Hacettepe University Journal of Education, 21, 1-8.

Ateş, A., \& Altun, E. (2008). Investigating Preservice Computer Teachers Attitudes Towards Distance Learning Regarding Various Variables. Gazi University Journal of Gazi Eduational Faculty, 28(3), 125-145.

Aydemir, m. (2018). Distance Education Program, Course and Material Design. [Uzaktan Ĕgitim Program, Ders ve Materyal Tasarımı]. Ankara: Eğitim Yayınevi.

Bloom, B. S. (1979). Human Qualities and Learning at School [İnsan Nitelikleri ve Okulda Öğrenme]. (D. A. Özçelik, Çev.) Ankara: Eğitim Yayınevi.

Büyüköztürk, Ş. (2002). Factor Analysis: Basic Concepts and Using to Development Scale. Educational Administration in Theory \& Practice, 32, 470-483.

Büyüköztürk, Ş. (2011). Data Analysis Handbook for Social Sciences - Statistics, Research Design, Spss Applications and Interpretation [Sosyal Bilimler Için Veri Analizi El Kitabı - İstatistik, Araştırma Deseni, Spss Uygulamaları ve Yorum] (15 b.). Ankara: Pegem Akademi.

Can, E. (2020). Coronavirus (Covid-19) pandemic and its pedagogical reflections: Open and distance education practices in Turkey. Açıöğretim Uygulamaları ve Araştırmaları Dergisi, 6(2), 11-53.

Chaplin, R. P. (2000). Beyond exam results? Differences in the social and psychological perceptions of young males and females at school. Educational Studies, 26(2), 177190.

Child, D. (2006). The essentials of factor analysis (3 b.). London: Continuum.

Cronbach, L. J. (1951). Coefficient alpha and the internal structure of tests. Psychometrika.

Çavuş, H., \& Gökdaş, İ. (2006). The Benefiting Reasons From Internet And The Gains Of The Educational Faculty Students. Van Yuzuncu Yil University Journal of Education, 3(2), 56-78.

Downey, J. (2006). Measuring General Computer Self-efficacy: The Surprising Comparison of Three Instruments in Predicting Performance, Attitudes, and Usage. Proceedings of the 39th Hawaii International Conference on System Sciences, (s. 210).

Ertmer, P. A., Ottenbreit-Leftwich, A. T., Sadık, O., Şendurur, E., \& Şendurur, P. (2012). Teacher beliefs and technology integration practices: A critical relationship. Computers and Education, 59, 423-435.

Freidmen, I. A. (2003). Self-efficacy and burnout in teaching: The importance of interpersonal-relations efficacy. Social Psychology of Education, 6, 191-215. 
Ghaith, G., \& Shaaban, K. (1999). The relationship between perceptions of teaching concerns, teacher efficacy, and selected teacher characteristics. Teaching and Teacher Education, 15(5), 471-485.

Horzum, M. B., \& Çakır, Ö. (2009). The Validity and Reliability Study of the Turkish Version of the Online Technologies Self-Eficacy Scale. Educational Sciences: Theory \& Practice, 9(3), 1327-1356.

Jacobsen, D. A., Eggen, p., \& Kauchak, D. (2002). Methods for teaching, Promoting student learning, (6 b.). New Jersey: Meririll Prentice Hall.

Kula Kartal, S., \& Mor Dirlik, E. (2016). Historical Development Of The Concept Of Validity And The Most Preferred Technique Of Reliability: Cronbach Alpha Coefficient. Bolu Abant Izzet Baysal University Journal of Faculty of Education, 16(4), 1865-1879.

MacCallum, R. C., Widaman, K. F., Zhang, S., \& Hong, S. (1999). Sample size in factor analysis. Psychological Methods. Psychological Methods, 4(1), 84-99. doi:10.1037/1082-989X.4.1.84

Naylor, D., \& Nyanjom, J. (2020). Educators' emotions involved in the transition to online teaching in higher education. Higher Education Research \& Development, 1-15. doi:10.180/07294360.2020.1811645

Ornstein, A. C., \& Lasley, T. J. (2000). Strategies for effective teaching. USA: McGraw-Hill higher Education Companies.

Öztürk, P., \& Kert, S. (2017). The Effect of an Online Learning Environment on Adults' Perception of Self-efficacy and Academic Achievement. Acta Infologica, 1(1), 39-54.

Patricia, A. (2020). College students' use and acceptance of emergency online learning due to COVID-19. International Journal of Educational Research Open, 99(104), 1-33.

Randel, B., Stevenson, H. W., \& Witruk, E. (2000). Attitudes, beliefs, and mathematics achievement of German and Japanese high school students. International Journal of Behavioral Development, 24(2), 190-198.

Santiago, A. M., \& Einerson, M. K. (1998). Background Characteristics As Predictors Of Academic Self-Confidence And Academic Self-Efficacy Among Graduate Science And Engineering Students. Research in Higher Education, 39(2), 163-198.

Schlosser, A., \& Simonson, M. (2009). Distance Education: Definition and Glossary of Terms (3 b.). U.S: Information Age Publishing.

Schriver, M., \& Czerniak, C. M. (1999). A Comparison of Middle And Junior High Science Teachers Levels of Efficacy And Knowledge of Developmentally Appropriate Curriculum And Instruction. Journal of Science Teacher Education, 10(1), 21-42.

Tarlakazan, E., \& Tarlakazan, B. E. (2020). Covid 19 Distance Education Studies in Turkey During The Pandemic Process: Case of Kastamonu University. Turkish Stuies, 15(7), 3107-3122.

Tavşancıl, E. (2014). Measuring Attitudes and Data Analysis with Spss [Tutumların Ölçülmesi ve Spss Ille Veri Analizi] (5 ${ }^{\text {th }}$. Ed.). Ankara: Nobel Yayınevi.

Woodcock, S., Sisco, A., \& Eady, M. (2105). The learning experience: Training teachers using online synchronous environments. Journal of Educational Research and Practice, 5(1), 21-34.

Yaman, S. (2016). Adapting of Science Learning Self-Efficacy Belief Scale for Middle School Students: Validity and Reliability Study. Inönü University Journal of the Faculty of Education, 17(2), 123-140.

Yaman, S., Cansüngü Koray, Ö., \& Altunçekiç, A. (2004). A Research On The Investigation Of The Self-Sufficiency Belief Levels Of The Science Education Teacher Candidates. The Journal of Turkish Educational Sciences, 2(3), 355-366. 
Yaşlıoğlu, M. M. (2017). Factor Analysis and Validity in Social Sciences: Application of Exploratory and Confirmatory Factor Analyses. Istanbul Business Research, 46(Özel Say1), 74-85.

Yıldız, E., \& Seferoğlu, S. S. (2020). Examination of Self-Efficacy Perception of Distance Education Students About Online Technologies. Manisa Celal Bayar University Journal fo social Sciences, 18(1), 33-46.

Y1ld1z, M. (2015). The Relationships Among Distance Education Instructors' Konwledge, Belief and Practices Towards Distance Education. Retrieved 2021, from https://tez.yok.gov.tr/UlusalTezMerkezi/tezDetay.jsp?id=e2a0d55V78tzkNCkMv9kZ g\&no=76GnW4vvHv3BtStUcIKqMw

Zusho, A., \& Pintrich, P. R. (2003). Skill and will: The role of motivation and cognition in the learning of college chemistry. Internatioanal Journal of Science Education, 25(9), 1081-1094. 


\section{Appendix}

\section{Uzaktan Eğitim Öz-Yeterlik İnanç Ölçeği}

\begin{tabular}{|c|c|c|c|c|c|c|}
\hline No & Maddeler & 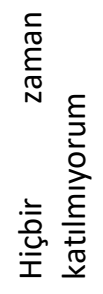 & 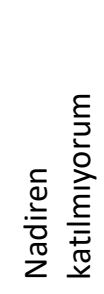 & 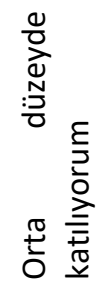 & 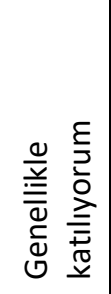 & 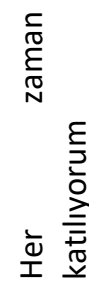 \\
\hline 2 & $\begin{array}{l}\text { Uzaktan eğitimde ders esnasında bir sorunla karşılaştığımda } \\
\text { kendim çözebilirim }\end{array}$ & $\mathrm{O}$ & $\mathrm{O}$ & $\mathrm{O}$ & $\mathrm{O}$ & $\mathrm{O}$ \\
\hline 3 & $\begin{array}{l}\text { Uzaktan eğitim uygulamalarını kullanmada güçlük çeken } \\
\text { arkadaşlarıma yardımcı olabilirim }\end{array}$ & $\mathrm{O}$ & $\bigcirc$ & $\mathrm{O}$ & $\mathrm{O}$ & $\mathrm{O}$ \\
\hline 5 & Her türlü uzaktan eğitim platformunu rahatlıkla kullanabilirim & $\mathrm{O}$ & $\mathrm{O}$ & $\mathrm{O}$ & $\mathrm{O}$ & $\mathrm{O}$ \\
\hline 6 & $\begin{array}{l}\text { Uzaktan eğitim uygulamalarında kendimi arkadaşlarımın } \\
\text { çoğundan daha yetenekli bulurum }\end{array}$ & $\mathrm{O}$ & O & $\mathrm{O}$ & $\mathrm{O}$ & $\mathrm{O}$ \\
\hline 7 & $\begin{array}{l}\text { Uzaktan eğitim uygulamaları alanında yeteri kadar bilgiye } \\
\text { sahip olduğumu düşünüyorum }\end{array}$ & $\mathrm{O}$ & $\mathrm{O}$ & $\mathrm{O}$ & O & $\mathrm{O}$ \\
\hline 8 & $\begin{array}{l}\begin{array}{l}\text { Uzaktan eğitim ortamlarında } \\
\text { düşünüyorum }\end{array} \\
\text { ders verebileceğimi }\end{array}$ & $\mathrm{O}$ & $\mathrm{O}$ & $\mathrm{O}$ & O & O \\
\hline 9 & $\begin{array}{l}\text { Uzaktan eğitim ders sırasında beyaz tahta gibi interaktif } \\
\text { özellikleri etkili bir şekilde kullanabilirim }\end{array}$ & $\mathrm{O}$ & $\mathrm{O}$ & $\mathrm{O}$ & $\mathrm{O}$ & 0 \\
\hline 10 & $\begin{array}{l}\text { Uzaktan eğitim ders sırasında iletişim araçlarını (mikrofon, } \\
\text { kamera, mesaj) rahatlıkla kullanabilirim }\end{array}$ & 0 & 0 & 0 & 0 & 0 \\
\hline 11 & $\begin{array}{l}\text { Uzaktan eğitim ders sırasında paylaşım araçlarını (dosya, } \\
\text { ekran) rahatlıkla kullanabilirim }\end{array}$ & 0 & 0 & 0 & 0 & 0 \\
\hline 12 & $\begin{array}{l}\text { Uzaktan eğitim yolu ile aldığım derslerde başarılı } \\
\text { olabileceğime inanıyorum }\end{array}$ & 0 & 0 & 0 & 0 & 0 \\
\hline 13 & $\begin{array}{l}\text { Uzaktan eğitim yolu ile aldığım dersleri heyecan verici } \\
\text { bulurum }\end{array}$ & 0 & 0 & 0 & 0 & 0 \\
\hline 14 & $\begin{array}{l}\text { Uzaktan eğitim yolu ile aldığım dersler süresince } \\
\text { arkadaşlarımla verimli çalışmalar yürütebilirim }\end{array}$ & 0 & 0 & 0 & 0 & 0 \\
\hline 15 & $\begin{array}{l}\text { Uzaktan eğitim yolu ile aldığım derslerde öğretmenimin } \\
\text { benden beklentisinden daha fazlasını yapmaya çalışırım }\end{array}$ & 0 & 0 & 0 & 0 & 0 \\
\hline 16 & $\begin{array}{l}\text { Uzaktan eğitim yolu ile aldığım derslere geçmek amacıyla değil } \\
\text { öğrenmek amacıyla katılıım }\end{array}$ & 0 & 0 & 0 & 0 & 0 \\
\hline 17 & $\begin{array}{l}\text { Uzaktan eğitim yolu ile aldığım derslerde en başarılı } \\
\text { öğrencilerden biri olmak beni mutlu eder }\end{array}$ & 0 & 0 & 0 & 0 & 0 \\
\hline 18 & $\begin{array}{l}\text { Uzaktan eğitim yolu ile aldığımda dersle ilgili arkadaşlarımın } \\
\text { sorularına cevap verebilirim }\end{array}$ & 0 & 0 & 0 & 0 & 0 \\
\hline 19 & $\begin{array}{l}\text { Uzaktan eğitim yolu ile aldığım dersleri çok iyi } \\
\text { öğrenebileceğimi düşünüyorum }\end{array}$ & 0 & 0 & 0 & 0 & 0 \\
\hline 20 & $\begin{array}{l}\text { Uzaktan eğitim yolu ile aldı̆̆ım derslerde başkalarının başarılı } \\
\text { olduğunu gördüğümmde ben de daha fazla çalışmak isterim }\end{array}$ & 0 & 0 & 0 & 0 & 0 \\
\hline 21 & $\begin{array}{l}\text { Uzaktan eğitim yolu ile öğrendiğim bilgileri ders tekrar izleme } \\
\text { özelliği ile pekiştirebilirim }\end{array}$ & 0 & 0 & 0 & 0 & 0 \\
\hline
\end{tabular}

